\title{
MYCELIAL GROWTH AND SCLEROTIA PRODUCTION OF PLEUROTUS TUBER-REGIUM (FRIES) SINGER ON FOUR SAWDUST TYPES AT THREE COMPOSTING INTERVALS
}

\author{
RAST MICELIJA I PROIZVODNJA SKLEROCIJE \\ PLEUROTUS TUBER-REGIUM (FRIES) SINGER NA \\ ČETIRI VRSTE PILJEVINE U TRI INTERVALA KOMPOSTIRANJA
}

\author{
C. A. Otunla, S. G. Jonathan, O.O. Idowu, O. J. Olawuyi
}

\begin{abstract}
Mushrooms are consumed for their flavor, aroma, nutritive and medicinal values. The basis of this study is to boost protein production for human consumption. Studies were conducted to investigate the growth and yield of Pleurotus tuber-regium (Fr) Singer on four sawdust types derived from mango, cassia, neem and their mixed bed. The treatments consisted of factorial combination in complete randomized design at three different weeks of composting intervals (WCI) of 4,8 and 12 in three replicates. A progressive increment in the growth and yield parameters was observed. The data taken were sclerotia weight (SW), biological efficiency (BE), production efficiency $(\mathrm{PE})$, mycelia extension and average extension per day. Data collected were subjected to analysis of variance and the means were separated by Duncan's multiple range test. The results obtained revealed that while cassia sawdust substrate produced was best in terms of SW, BE and PE (35.34 g, 33.66\% and $13.51 \%$ respectively) at $8 \mathrm{WCI}$, mango sawdust produced the highest SW $(37.44 \mathrm{~g}), \mathrm{BE}(35.66 \%)$ and $\mathrm{PE}(18.28 \%)$ at $12 \mathrm{WCI}$. While the mixed bed produced the least SW at both 4 and 8 WCI in comparison with others, neem produced the least $\mathrm{SW}$ at $12 \mathrm{WCI}$. However, the longest mycelia extensions and extension per day were obtained in neem at the 4 and 8 WCI. As the composting intervals increased, there was a significant increment in the yield from mango sawdust thus making it the best among all the sawdusts investigated in this study.
\end{abstract}

Key words: Composting intervals, biological efficiency, production efficiency, Pleurotus tuber-regium, cassia (Senna siamea), mango (Mangifera indica) and neem (Azadirachta indica) 
Otunla, C.A. at al.: Mycelial growth and sclerotia production of Pleurotus tuber-regium (Fries) singer on four sawdust types at three composting intervals

\section{SAŽETAK}

Gljive se jedu zbog svog okusa i arome te hranjive i zdravstvene vrijednosti. Temelj ovog rada je potaknuti proizvodnju bjelančevina za ljudsku upotrebu. Provedena su istraživanja rasta i prinosa Pleurotusa tuber-regium (Fr) Singer na četiri vrste piljevine, od manga, kasije, nima i njihove mješavine. Postupci su se sastojali od faktorske kombinacije $\mathrm{u}$ potpunom randomiziranom dizajnu u tri različita tjedna razdoblja kompostiranja (TRK), 4, 8 i $12 \mathrm{u}$ tri ponavljanja. Primijećeno je progresivno povećanje parametara rasta i prinosa. Zabilježeni su podaci o težini sklerocije, biološkoj djelotvornosti, proizvodnoj djelotvornosti, rastu micelija i prosječnom rastu po danu. Prikupljeni podaci podvrgnuti su analizi varijance, a srednje vrijednosti su odvojene pomoću Duncanovog multiple range testa. Dobiveni su rezultati pokazali da dok je supstrat piljevine najbolji u smislu težine sklericije (ST), biološke djelotvornosti (BD), proizvodne djelotvornosti (PD) $(35,34 \mathrm{~g}, 33,66 \%$ i 13,51\%) u 8 TRK mango piljevina proizvela je najviši TS $(37,44 \mathrm{~g}), \mathrm{BD}(35,66 \%)$ i PD $(18,28 \%)$ u 12 TRK. Dok je smjesa od miješavine proizvela najmanje TS u 4 i 8 TRK u usporedbi s drugima, na supstratu nima proizvedeno je najmanje TS u 12 TRK. Međutim, najdulje proširenje micelija i proširenje po danu dobiveni su u smjesi od nima u 4 i 8 TRK. S povećanjem intervala kompostiranja došlo je do znatnog povećanja prinosa na piljevini manga, što ga čini najboljim od svih piljevina proučavanih u ovom radu.

Ključne riječi: razdoblja kompostiranja, biološka djelotvornost, proizvodna djelotvornost, Pleurotus tuber regium, sijamska kasija (Senna siamea), mango (Mangifera indica), nim (Azadirachta indica)

\section{INTRODUCTION}

For a common man, mushrooms are considered as one of the curiosities of nature and many of them are widely consumed for their flavor and aroma. Their nutritive and medicinal values were known as early as $1500 \mathrm{BC}$ based upon many works of ancient literature (Wasserand Weis, 1999). They are used in traditional medicine throughout the world since ancient times as 'the ultimate health food' (King, 1993). They have been universally recognized now as food and are grown on commercial scale in many parts of the world including Nigeria (Onuoha, 2007). Mushrooms are considered a delicacy with high nutritional and functional value, and they are also accepted as nutraceutical foods; they are of considerable interest because of their organoleptic merit, 
Otunla, C.A. at al.: Mycelial growth and sclerotia production of Pleurotus tuber-regium (Fries) singer on four sawdust types at three composting intervals

medicinal properties and economic significance (Ergönül et al., 2013). Pleurotus tuber-regium (Fr) Singer is one of the species commonly eaten in Nigeria (Oso, 1977; Ogunlana, 1992).

According to Fasidi and Ekuere (1993), the cultivation of P. tuber-regium amounts essentially for cropping of the sclerotia. Furthermore, their preliminary investigation revealed that its mycelium grows in the temperature of $20-40{ }^{\circ} \mathrm{C}$ (optimum $30{ }^{\circ} \mathrm{C}$ ) and $\mathrm{pH}$ range of 4-9 (optimum 6.0-7.0). Stamets (2001) observed that the fungus is often found growing around the African breadfruit (Treculia africana). It attacks dead wood, on which it produces globose or ovoid sclerotia which can sometimes be up to $30 \mathrm{~cm}$ or more in diameter (Oso, 1977). The sclerotia are dark brown on the outside and whitish on the inside, and may be found in the host (decaying wood). The local people who use this fungus for food and medicine usually collect the sclerotia in the wild, but it is getting difficult to find sclerotia due to the depletion of its forest habitat (Okhuoya, and Ajerio, 1988).

In Nigeria, it is consumed, not only for its flavor and nutritive value, but also for its beneficial and medicinal effects (Oso, 1977; Kadiri and Fasidi, 1990; Isikhuemhen and Okhuoya, 1995; Okhuoya et al., 1996). It is used in the Asaba area of Nigeria as herbal preparation for pregnant women to aid the development of foetus. In Ghana, the sclerotia are used mainly for fattening malnourished babies and as one of the ingredients for the embalming of dead bodies (Okhuoya et al., 1998). Analysis of sclerotia of P. tuber-regium has shown the presence of Calcium, Magnesium, Iron and Zinc (Okhuoya and Ajerio, 1988).

In developing countries, there is increasing demand for dietary protein production from readily available and affordable sources. Mushrooms have high contents of good quality protein, crude fibre and minerals (Kadiri and Fasidi, 1990). Pleurotus species (oyster mushrooms) are potential protein supplements and grow naturally on wood wastes. Nakalembe et al. (2015) stated that protein content varied between 17.58 and $27.43 \%$ on a dry weight basis for Pleurotus tenucuilus (sub-humid) and Termitomyces microcarpus (humid region) making up to $35.2-54.9 \%$ of $50 \mathrm{~g}$ of protein/day of Recommended Daily Intake (RDI), which is within the average value of $19-35 \%$ dry weight of dried mushrooms. The dwindling forests and the absence of commercial cultivation of this fungus has resulted in the scarcity of sclerotia, thus making the few available very expensive. As a result, there arises the need for commercial cultivation to supplement collection from the wild (Apetorgbor et al., 2013). Adedokun et al. 
Otunla, C.A. at al.: Mycelial growth and sclerotia production of Pleurotus tuber-regium (Fries) singer on four sawdust types at three composting intervals

(2003) stated that mushroom cultivation requires little space but much labour and it can be an important means for small scale farmers and land labourers to increase their income. Nigeria is richly endowed with good quality mushrooms like Pleurotus and Agaricus genera which should be mass-produced for local consumption as well as for international market (Onuoha, 2007). The need for commercial production of all edible mushrooms in Nigeria cannot be overemphasized in view of its potential contribution to agricultural production and as a source of cheap protein (Onuoha, 2007). It equally takes care of environmental pollution as it converts wastes to wealth. Hence, an attempt was made in this research study to evaluate the mycelial growth and sclerotia yield of $P$. tuber-regium on four different types of sawdusts.

\section{MATERIALS AND METHODS}

This research project was conducted at the mycology laboratory of the National Horticultural Research Institute (NIHORT), Ibadan located in the forest Savannah zone of South-West Nigeria (Latitude $7^{\circ} 22^{\prime} \mathrm{N}$, Longitude $3^{\circ} 50^{`} \mathrm{E}$ ).

Source of substrates

The cassia (Senna siamea), mango (Mangifera indica) and neem (Azadirachta indica) trees used for this research work were obtained within the premises of the National Horticultural Research Institute (NIHORT), Ibadan. They were identified by the floriculture unit of NIHORT. After obtaining these substrates (trunks with their bark), they were milled separately at Sanngo sawmill, Ibadan and stored in the mushroom laboratory, NIHORT.

\section{Source of spawn}

The spawns of Pleurotus tuber-regium were obtained from the mushroom unit, NIHORT, Ibadan. The inocula used was generated from the mushroom sporophore obtained at Songhai farm in Porto Novo in Benin Republic and maintained on Potato Dextrose Agar (PDA) for regular sub-culturing as described by Quimio et al. (1990).

\section{Research Design}

It was a factorial experiment in a complete randomized design with 3 replicates. For the evaluation of mycelia growth, each treatment was replicated three times and incubated at room temperature of $30 \pm 2{ }^{\circ} \mathrm{C}$. 
Otunla, C.A. at al.: Mycelial growth and sclerotia production of Pleurotus tuber-regium (Fries) singer on four sawdust types at three composting intervals

Mycelial growth on sawdusts

The sawdusts (substrates) were from Senna siamea, Mangifera indica and Azadirachta indica with their mixed bed derived from the mixtures of the three substrates in equal proportions by weight. Water was added to the four substrates separately until the moisture content was about $65 \%$. They were filled into $(2.3 \mathrm{~cm} \times 15 \mathrm{~cm})$ test tubes according to the method of Fasidi and Ekuere (1993), sealed with cotton plug and aluminium foil. They were sterilized at $121^{\circ} \mathrm{C}$ for $15 \mathrm{~min}$ in an autoclave. Each treatment was replicated 3 times. After cooling, each one was inoculated with freshly prepared spawn and incubated at room temperature $\left(30 \pm 2{ }^{\circ} \mathrm{C}\right)$ for 2 weeks. These procedures were repeated in the treatments when the sawdusts were 4,8 and 12 weeks old at storage.

\section{Cultivation of tuber (sclerotia)}

The 4 sawdust types were packed into $300 \mathrm{~g}$ samples after moistening with water to about $65 \%$ in transparent polyethylene bags of size $25 \times 15 \mathrm{~cm}$. The neck of the bag was prepared using heat resistant PVC (Poly Vinyl Chloride) tube, plugged with cotton wool, replicated 3 times and sterilized in an autoclave at $121{ }^{\circ} \mathrm{C}$ for $15 \mathrm{~min}$. The sterilized substrate bags were allowed to cool, inoculated asceptically with $30 \mathrm{~g}$ of the mushroom spawn and transferred into the incubation (vegetative) room at the temperature of $30 \pm 2{ }^{\circ} \mathrm{C}$. After incubation in the dark/ vegetative room for $3 \frac{1}{2}$ months, the bags were weighed and the sclerotia were harvested and weighed in accordance with the method of Fasidi and Ekuere (1993). The biological efficiency of the substrates was calculated according to the method of Khanna and Garcha (1982). These procedures were repeated on the treatments at the different composting intervals of 4,8 and 12 weeks.

\section{Data Analysis}

Data obtained were analysed by ANOVA while means were separated using Duncan's multiple range test.

\section{RESULTS AND DISCUSSION}

The mycelium of $P$. tuber-regium grew well on all four types of sawdusts (Table 1). This agrees with the previous works of various researchers (Oei, 2003; Saidu et al., 2011; Otunla and Idowu, 2012; Idowu et al., 2015). Earlier, Kadiri and Fasidi (1990) stated that sawdust was consistently the best substrate 
Otunla, C.A. at al.: Mycelial growth and sclerotia production of Pleurotus tuber-regium (Fries) singer on four sawdust types at three composting intervals

in supporting mycelia growth and fructification. Many lignocellulosic substrates can support growth of P. tuber-regium (Isikhuemhen and Nerud, 1999). The sawdusts have lignin and cellulose which can be easily colonized and degraded by edible mushrooms (Sánchez, 2010). This growth could be attributed to the availability of lignin and cellulose in the sawdusts. The ability of the mushroom to secrete hydrolyzing and oxidizing enzymes could have aided the decomposition (Jonathan et al., 2008). As decomposition advanced, more nutrients were released. Girmay et al. (2016) supported a long period of composting to breakdown the cellulose and lignin components of wood in order to release the essential materials for mycelia establishment. At 4 weeks of composting interval (WCI), the longest mycelia extension was observed in neem $(4.88 \mathrm{~cm})$ followed by mango $(3.00 \mathrm{~cm})$ while the least was in the mixed bed $(1.13 \mathrm{~cm})$. Of the three levels, however, the longest mycelia extension per day in all the treatments was observed at $8 \mathrm{WCI}$. The longest mycelia extension $(10.38 \mathrm{~cm})$ was obtained in mango, as substrate, at $8 \mathrm{WCI}$ which was not significantly different from what was observed in neem $(10.13 \mathrm{~cm})$. The least was in cassia $(6.88 \mathrm{~cm})$. At $12 \mathrm{WCI}$, what was obtained in cassia, mixed bed and neem was not statistically different from one another $(7.88 \mathrm{~cm}, 7.50 \mathrm{~cm}$ and $7.00 \mathrm{~cm}$ respectively) while the least was observed in mango $(5.63 \mathrm{~cm})$. The shortest mycelia extension recorded in mango (at $12 \mathrm{WCI}$ ) in comparison to other substrates could be attributed to maximizing the available nutrients for the mushroom.

A progressive increment in both biological and production efficiencies was observed as WCI increased. At 4WCI, the biological efficiency (BE) of mango was the highest (22.14\%) followed by cassia and neem which were not significantly different from each other; $16.47 \%$ and $14.78 \%$ respectively (Table $1)$. The least was observed in mixed bed $(8.57 \%)$. At $8 \mathrm{WCI}$, the highest BE was observed in cassia (33.66\%) with the other substrates in this trend; mango $>$ neem $>$ mixed bed. At $12 \mathrm{WCI}$, the highest $\mathrm{BE}(35.66 \%)$ was recorded in mango which was not significantly different from what was obtained in mixed bed and cassia (35.25\% and 33.17\% respectively). Neem recorded the least.

Recorded Biological Efficiency (BE) and Production Efficiency (PE) followed the same trend at $4 \mathrm{WCI}$ and $8 \mathrm{WCI}$ (mango $>$ cassia $>$ neem $>$ mixed). PE was the highest in mango (8.25\%) and in cassia (13.51\%) at 4 and 8 WCI respectively (Table 1). However, the trend was different at $12 \mathrm{WCI}$. The highest was obtained in mango (18.28\%) followed by the mixed bed (16.22\%) which was statistically different from what was obtained in cassia $(14.22 \%)$ 
Otunla, C.A. at al.: Mycelial growth and sclerotia production of Pleurotus tuber-regium (Fries) singer on four sawdust types at three composting intervals

while neem recorded the least $(11.09 \%)$. The same trend was observed at the three levels of WCI in the average extension per day (Table 1). The longest was observed in neem while the remaining substrates were in the order; mango, mixed bed and cassia, as the shortest. The sawdusts were from different wood types, there may be presence of particles in the wood that may tend to inhibit the growth of the fungus (Davis and Aegerter, 2000). The values of biological and production efficiencies observed varied as a result of the biological structure of the substrates used in this study. This was also observed by Akyüz and Yildiz (2007) and Akyüz and Yildiz (2008). The variations may also stem from the differences in the nutrient content of the materials as decomposition progressed.

Table 1 The performance of the substrates as affected by weeks of composting intervals (WCI) on the Mycelial Extension, Extension per Day, Biological Efficiency and Production Efficiency of Pleurotus tube- regium

Tablica 1. Djelovanje supstrata nakon tjedana razdoblja kompostiranja na rast micelija, rast po danima, biološku djelotvornost i proizvodnu djelotvornost Pleurotus-a tuber-regium

\begin{tabular}{|c|c|c|c|c|c|c|c|c|c|c|c|c|}
\hline \multirow[t]{3}{*}{$\begin{array}{c}\text { Substrate } \mathrm{x} \\
\text { WCI }\end{array}$} & \multicolumn{3}{|c|}{$\begin{array}{l}\text { Mycelial Extension } \\
(\mathrm{cm})\end{array}$} & \multicolumn{3}{|c|}{$\begin{array}{l}\text { Extension per Day } \\
(\mathrm{cm})\end{array}$} & \multicolumn{3}{|c|}{$\begin{array}{c}\text { Biological Efficiency } \\
(\%)\end{array}$} & \multicolumn{3}{|c|}{$\begin{array}{c}\text { Production Efficiency } \\
(\%)\end{array}$} \\
\hline & \multicolumn{3}{|c|}{ Weeks } & \multicolumn{3}{|c|}{ Weeks } & \multicolumn{3}{|c|}{ Weeks } & \multicolumn{3}{|c|}{ Weeks } \\
\hline & 4 & 8 & 12 & 4 & 8 & 12 & 4 & 8 & 12 & 4 & 8 & 12 \\
\hline Mango & $3.00 \mathrm{~b}$ & $10.38 \mathrm{a}$ & $5.63 b$ & $0.41 b$ & $0.45 \mathrm{~b}$ & $0.63 b$ & $22.14 \mathrm{a}$ & $30.87 b$ & $35.66 \mathrm{a}$ & $8.25 \mathrm{a}$ & $12.40 \mathrm{~b}$ & $18.28 \mathrm{a}$ \\
\hline Cassia & $2.00 \mathrm{c}$ & $6.88 \mathrm{c}$ & $7.88 \mathrm{a}$ & $0.32 \mathrm{~d}$ & $0.35 \mathrm{~d}$ & $0.52 \mathrm{~d}$ & $16.47 \mathrm{~b}$ & $33.66 \mathrm{a}$ & $33.17 \mathrm{a}$ & $6.07 \mathrm{~b}$ & $13.51 \mathrm{a}$ & $14.12 \mathrm{c}$ \\
\hline Neem & $4.88 \mathrm{a}$ & 10.13a & $7.00 \mathrm{a}$ & $0.44 a$ & $0.48 \mathrm{a}$ & $0.68 \mathrm{a}$ & $14.78 \mathrm{~b}$ & $18.08 \mathrm{c}$ & $25.50 \mathrm{~b}$ & $5.51 \mathrm{~b}$ & $7.35 \mathrm{c}$ & $11.09 \mathrm{~d}$ \\
\hline Mixed Bed & $1.13 \mathrm{~d}$ & $9.00 \mathrm{~b}$ & $7.50 \mathrm{a}$ & $0.36 \mathrm{c}$ & $0.41 \mathrm{c}$ & $0.58 \mathrm{c}$ & $8.57 \mathrm{c}$ & $16.14 d$ & $35.25 \mathrm{c}$ & $3.23 \mathrm{c}$ & $6.78 \mathrm{c}$ & $16.22 \mathrm{~b}$ \\
\hline
\end{tabular}

Means with the same letter along the column are not significantly different from one another at $\mathrm{p} \leq 0.05$.

WCI: Weeks of Composting Intervals

TRK: Tjedan razdoblja kompostiranja

The different sawdust types had significant effect on the mushroom sclerotia yield. The sclerotia weight (SW) observed was the highest in mango (23.24 g), followed by cassia and neem which were comparable to each other $(17.30 \mathrm{~g}$ and $15.51 \mathrm{~g}$ respectively) at 4 WCI (Fig. 1) while the lowest was observed in mixed bed $(9.00 \mathrm{~g})$. However, at $8 \mathrm{WCI}$, the heaviest SW was obtained in cassia $(35.34 \mathrm{~g})$ followed by mango as substrate $(32.42 \mathrm{~g})$, (Fig. 1$)$. The least was also produced in mixed bed $(16.94 \mathrm{~g})$ which was observed at 4WCI. At 12WCI, the greatest SW was recorded in mango $(42.13 \mathrm{~g})$, followed by the mixed bed and cassia which were significantly different from each other $(37.02 \mathrm{~g}$ and $32.83 \mathrm{~g}$ respectively). Neem produced the least $(26.77 \mathrm{~g})$. Other researchers had 
Otunla, C.A. at al.: Mycelial growth and sclerotia production of Pleurotus tuber-regium (Fries) singer on four sawdust types at three composting intervals

reported various yield values for their mushroom cultivation (Ohga, 2000; Ragunathan and Swaminathan, 2003; Yildiz, 2003). Yield is determined by the substrate $\mathrm{pH}$, aeration, available nutrient, water contents and microbial activity (Oei, 1991). Abott et al. (2009) stated that mushroom yield was observed to be influenced by the use of sawdust of different wood types. Otunla (2015) also observed that the highest sclerotia weights were recorded on the sawdusts with the longest weeks of composting interval (WCI). This could be due to the biological and chemical differences between the substrates medium and genotype of the cultured mushroom as earlier observed by Imbernon (1990) and Olivier (1990). As sclerotia weight was the highest at 8WCI in cassia (Fig. 1), it was thought that beyond two months, decomposition in cassia had no significant effects on nutrient availability. At $4 \mathrm{WCI}$ and $12 \mathrm{WCI}$, the sclerotia weights were the highest in mango sawdust. Furthermore, mycelia density on mango sawdust at $12 \mathrm{WCI}$ was the highest which had a direct effect on the yield. This agreed with the earlier work by Thomas et al. (1998). The observed highest mycelial density could be a result of high level of aeration and porosity as mango trunk is a soft wood (Hami, 1990).

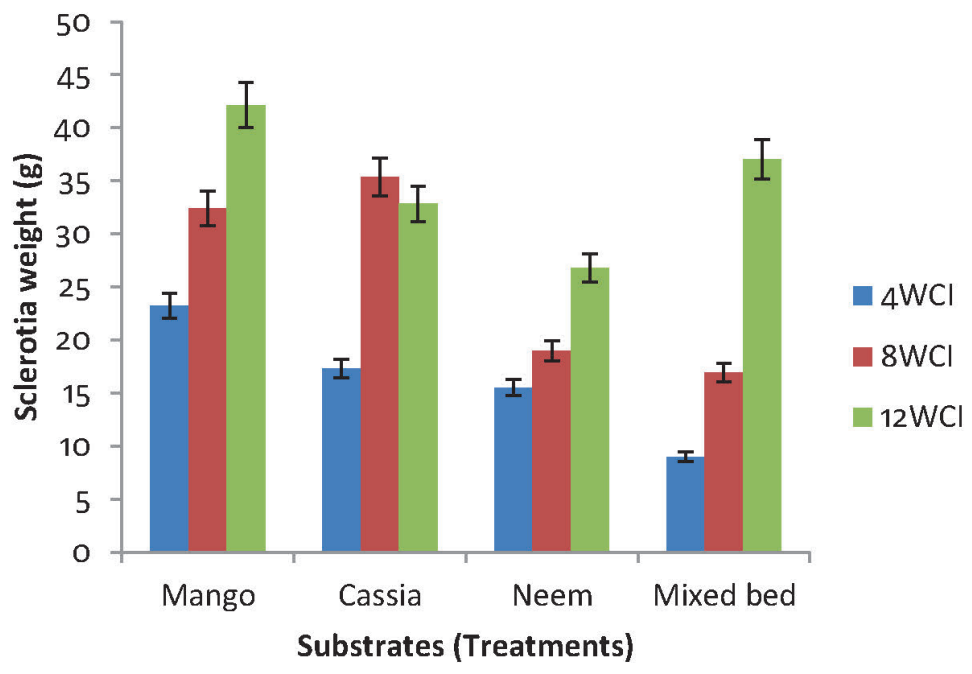

Figure 1 The performance of the substrates as affected by weeks of composting intervals (WCI) on the yield of Pleurotus tuber-regium

Slika 1. Djelovanje supstrata nakon tjedana razdoblja kompostiranja (TRK) na prinos Pleurotus-a tuber regium 
Otunla, C.A. at al.: Mycelial growth and sclerotia production of Pleurotus tuber-regium (Fries) singer on four sawdust types at three composting intervals

\section{CONCLUSION}

From this investigation, it is evident that sawdust from different sources can be used to cultivate $P$. tuber-regium. There was a significant increment in the yield from mango sawdust thus making it the best among all the sawdusts investigated in this study. Therefore, mango sawdust can be channeled towards the production of protein-rich sclerotia to boost cheap protein availability instead of burning the sawdusts which is a usual or common practice.

\section{ACKNOWLEDGEMENT}

We appreciate the support and technical assistances rendered by Mrs F.O. Akinrinsola, Mrs G.A. Majekadegbe and Mr M.O. Daropale.

\section{REFERENCE}

1. Abott, O.O., Okhuoya, J.A. and Akpeja, E.O. (2009): Growth of Lentinus squarrosulus on sawdust of different tropical trees. African Journal of Food Science. 3(1) 007-010.

2. Adedokun, M. Olutayo, V.I. Ayodele and I.O. Fasidi. (2003): Spawn production and cultivation of Pleurotus tuber-regium on agricultural wastes. Bioscience Research Communications. 15 (6): 437-444.

3. Akyüz, M. and Yıldız, A. (2007): Cultivation of Pleurotus eryngii (DC. ex Fr.) Quel. on agricultural wastes. Philipp. Agric. Sci. 90 (4): 346-350.

4. Akyüz, M. and Yıldız, A. (2008): Evaluation of cellulosic wastes for the cultivation of Pleurotus eryngii(DC. ex Fr.) Quel. Afr. J. Biotechnol. 7(10): 1494-1499.

5. Apetorgbor, A. K., Dzomeku, M. and Apetorgbor, M. M. (2013): Growth factors and cultivation of Pleurotus tuber-regium on selected plant wastes. International Food Research Journal 20 (6): 3387-3393.

6. Davis, R.A. and Aegerter, B.J. (2000): Edible Mushroom Cultivation. Scientific Publishers Jodhpur India; 2 - 5.

7. Ergönül, P.G., I. Akata, F. Kalyoncu, and B. Ergönül. (2013): Fatty acid compositions of six wild edible mushroom species, The Scientific World Journal, vol. 2013, Article ID 163964, 4 pages.

8. Fasidi, I.O. and Usukama, U. Ekuere (1993): Studies on Pleurotus tuberregium (Fries) Singer: cultivation, proximate composition and mineral contents of sclerotia. Food Chemistry 48: 255-258. 
Otunla, C.A. at al.: Mycelial growth and sclerotia production of Pleurotus tuber-regium (Fries) singer on four sawdust types at three composting intervals

9. Girmay Zenebe, Weldesemayat Gorems, Getachew Birhanu and Solomon Zewdie (2016): Growth and yield performance of Pleurotus ostreatus (Jacq. Fr.) Kumm (oyster mushroom) on different substrates. AMB Express. 6 (1): 87 (7 pages). Springer Open DOI 10.1186/s13568-016-0265-1.

10. Hami, H. (1990): Cultivation of oyster mushroom on sawdust of different woods. M.Sc. Thesis, University of Agriculture, Faisalabad, Pakistan.

11. Idowu, O.O., Otunla, C.A., Oke, A.O. and Adelaja, B.A. (2015): Efficiency of different concentrations of water hyacinth Eichhornia crassipes (Mart.) Solms.) and sawdust as substrate for the cultivation of Pleurotus ostreatus (Jacq. Ex. Fr.) Kummer (Oyster mushroom). Journal of Biological and Chemical Research. 32 (2): 564-572.

12. Imbernoon, M. (1990): Selection VarietaleChez Les Pleurotes Dossier Pleurote. In: Olivier JM (eds), I.N.R.A., Bordeux, pp. 14-25.

13. Isikhuemhen, O. S. and Nerud, F. (1999): Preliminary studies on the ligninolytic enzymes produced by the tropical fungus Pleurotus tuber-regium. Antonie van Leeuwenhoek 75: 257-260.

14. Isikhuemen, O. S. and Okhuoya, J. A. (1995): A low cost technique for the cultivation of Pleurotus tuber-regium (Fr) singer in developing tropical countries. Mushroom Growers News letter 4:2 - 4 .

15. Jonathan, S.G., L.T. Kigigha and E. Ohimain. (2008): Evaluation of the inhibitory potentials of Eight higher Nigerian Fungi against pathogenic Microorganisms. African Journal of Biomedical Research 11: 192-202.

16. Kadiri, M. and Fasidi, I.O. (1990): Variations in chemical compositons of Chromophyllum molybditis (Mayerex. Fr.) masses and Pleurotus tuber-regium (Fries) during fruitbody development. Nigerian J. Sci., 24: 86-89.

17. Khanna, P. and Garcha, H.S. (1982): Utilization of paddy straw for the cultivation of Pleurotus spp. Mushroom Newslett. Tropics, 2 (3):5-9.

18. King, T.A., 1993. Mushrooms, the ultimate health food but little research in U.S. to prove it. Mush. News. 41: 29-46.

19. Nakalembe, I., Kabasa, J.D. and Olila, D. (2015): Comparative nutrient composition of selected wild edible mushrooms from two agro-ecological zones, Uganda. Springer Plus. 4: 433. doi:10.1186/s40064-015-1188-z.

20. Oei, P. (1991): Manual on mushroom cultivation technique, species and opportunities for commercial applications in developing countries (First edition). Tool Foundation, Amsterdam, 249pp. 
Otunla, C.A. at al.: Mycelial growth and sclerotia production of Pleurotus tuber-regium (Fries) singer on four sawdust types at three composting intervals

21. Oei, P. (2003): Mushroom Cultivation: appropriate technology for mushroom growers. Backhuys Publishers Leiden, The Netherlands. pp 10-11. Ogunlana, S.K. (1992): Studies on the cultivation of the edible mushroom Pleurotus tuber-regium (Fr) Singer. Tropical Journal of Applied Sciences 2: $56-60$.

22. Ohga, S. (2000): Influence of wood species on the sawdust-based cultivation Pleurotus abalonusa and Pleurotus eryngii. J. Wood Sci.46: 175-179.

23. Okhuoya, J. A. and C. A. Ajerio. (1988): Analysis of Sclerotia and Sporophores of Pleurotus tuber-regium (Fr) Singer, an edible mushroom in Nigeria. Korean Journal of Mycology. 16:204 - 206.

24. Okhuoya, J. A., Eboigbe O. E. and Isikhuemhen, O. S. (1996): Growth interactions between Pleurotus tuber-regium (Fr.) Singer and Sclerotium rolfsii Sacc. Folia Microbiological. 41: 433 - 435.

25. Okhuoya, J. A., Isikhuemhen, O. S. and Evue, G. A. (1998): Pleurotus tuberregium (Fr.) Sing: sclerotia and sporophore yield during cultivation on sawdust of different woody plants. International Journal of Mushroom Sciences.2: $41-46$.

26. Olivier, J.M. (1990): Les besoins des Pleurotus cultives. Bull. Fnsacc. 45: 33-51.

27. Onuoha, C.I. (2007):Cultivation of the mushroom (Pleurotus tuber-regium) using some local substrates. Science Journal. 4(4): 58 - 61.

28. Oso BA. (1977): Pleurotus tuber-regiumfrom Nigeria. Mycologia 69: 271-279.

29. Otunla, C.A. (2015). Comparative study of the growth and yield of three cultivated Pleurotus species on selected tropical trees sawdusts. M. Phil Thesis, University of Ibadan, Nigeria pp 66-70.

30. Otunla, C.A. and O.O. Idowu. (2012): Comparative Study of the Growth and Yield of Pleurotus florida (Oyster mushroom) on Some Tropical Trees. Food 6 (1): 86-89.

31. Quimio, T. H., Chang, S. T. and Royse, D. J. (1990): "Technical guidelines for mushroom growing in the tropics", FAO Plant Production and Protection Paper 106, pp 160-170.

32. Ragunathan R. and Swaminathan K. (2003): Nutritional status of Pleurotus spp. Grown onvarious agro-wastes. Food Chemistry. 80(3): 371-375.

33. Saidu, M., Salim, M.R. and Yuzir A.M. (2011): Cultivation of oyster mushroom (Pleurotus spp.) on palm oil mesocarp fibre. African Journal of Biotechnology 10 (71): 15973-15976. 
Otunla, C.A. at al.: Mycelial growth and sclerotia production of Pleurotus tuber-regium (Fries) singer on four sawdust types at three composting intervals

34. Sánchez, C. (2010). Cultivation of Pleurotus ostreatus and other edible mushrooms. Appl. Microbiol. Biotechnol. 85:1321-1337.

35. Wasser, S.P. and A.L. Weis. (1999): Medicinal properties of substances occurring in higher Basidiomycetes mushrooms: Current perspectives (Review). Int. J. Med. Mush., 1: 31-62.

36. Stamets P. (2001): A novel approach to farm waste management. Mushroom Journal Winter 30: $28-32$.

37. Thomas, G.V., S.R. Prabhu, M.Z. Reeny and B.M. Bopaiah. (1998): Evaluation of lignocellulosic biomass from coconut palm as substrate for cultivation of Pleurotus sajor-caju (Fr) Singer. World Journal for Microbiology and Biotechnology 14: 879-882.

38. Yildiz, A. Karakaplan (2003): Evalulation of some agricultural wastes for the cultivation of edible mushrooms (P. ostreatus var salignus). J. Food Sci.Technol. 40: 290-292.

Author's addresses - Adrese autora:

Otunla, C.A.: corresponding author, e-mail: calebotunla@gmail.com

Idowu, O.O.

Vegetable Research Programme,

National Horticultural Research Institute.

P.M.B. 5432, Idi-Ishin, Jericho, Ibadan, Nigeria.

Jonathan, S.G.

Olawuyi, O.J.

Department of Botany, University of Ibadan, Ibadan.

Oyo State, Nigeria.
Received - Primljeno:

19.02.2018. 